\title{
In Defense of the Malthusian Interpretation of History
}

\author{
Gregory Clark, University of California, Davis \\ (gclark@ucdavis.edu)
}

\section{Introduction}

The four reviews make the following major criticisms of the book:

(1) A Farewell to Alms assumes one important revolution in economics history, the Industrial Revolution. In reality there were two, with the Neolithic Revolution of equal importance (George Grantham).

(2) World income levels did rise between the Stone Age and 1800 (Gunnar Persson, HansJoachim Voth).

(3) The Malthusian model has been shown to be inapplicable to pre-industrial Europe. (Grantham, Persson)

(4) The claim of "Survival of the Richest" just the revival of discredited and dangerous Social Darwinism? (Deirdre McCloskey)

(5) There was no Darwinian selection for "bourgeois characteristics" in the pre-industrial world of settled, institutionally stable agrarian societies (McCloskey)

(6) The recent growth of India and China, and the experience of immigrants to the USA easily refute the view that Survival of the Richest had any impact (McCloskey)

(7) The ideas of $A$ Farewell to Alms are not new, merely uncredited borrowings from others. (McCloskey, Persson, Voth) 


\section{The Neolithic Revolution}

For those interested in long run history, the Neolithic Revolution looms large. In $A$ Farewell to Alms this revolution is given very much a secondary role to the one great event in history, the Industrial Revolution. My thinking was that settled agriculture was really just a natural extension of hunting and gathering. Hunter-gatherers before the Neolithic Revolution had been steadily improving their efficiency over the course of at least 100,000 years. Indeed archeologists of the Paleolithic have posited their own Upper Paleolithic Revolution (Stiner et al., 1999, Bar-Yusef, 2002). Rates of change of technology in the so-called "Neolithic Revolution" were also an order of magnitude lower than in the later Industrial Revolution.

The book thus conceives of a gradual evolutionary process. Hunter-gatherer societies, with little trade, little capital and much violence, give way to settled agrarian societies which are trade and capital intensive and more pacific. The evolution of the institutions of settled agrarian society markets, secure property rights, inheritance, limits on violence - is seen as stemming from the technology they employed. This through the operations of the Malthusian processes leads to a change in human nature and eventually much faster economic growth.

Once we follow this logic the tremendous advantage that East Asia and Europe had in technology over Africa, the Americas, and Oceania by 1500 would have to stem from some geographic advantage they had that have led to faster development of settled agriculture in these areas. History would again ultimately be determined by geography, as in Guns, Germs and Steel (Diamond, 1997).

I now feel that this simple picture is incorrect. That there was another important phase transition in history preceding the Industrial Revolution, but NOT the Neolithic Revolution. What gives me pause is the example of settled agrarian societies like the tribes of Papua New Guinea, who operate settled systems of capital intensive agriculture, but still in a social setting where violence is 
omnipresent, and economic success dependent heavily on family connections, and success in violence.

The Huli of Papua New Guinea, for example, who inhabit the southern Highlands, had a settled system of agriculture in 1960 that revolved around sweet-potato gardens, fruit trees, and pig rearing. Wealth is accumulated in the form of pigs mainly, and in control over gardens. Yet this was a society where low level conflict was endemic. Genealogical interviews suggested that $20 \%$ of male deaths (and 6\% of female deaths) were from warfare or violence (Glasse, 1968, 98). This is a fantastically high rate compared to societies such as England in the years 1200-1800. The sources of these conflicts were numerous: murders, failure to pay indemnities from earlier wars, breaches of bride price rules, theft, land encroachment, unpaid debts, and rape. Huli behavior in these respects was dominated by impulsiveness. "Huli are volatile and quick tempered; they lack deliberation and they swiftly resort to arms." (Glasse, 1968, 107).

Further in Huli society though high social status was associated with wealth, the causation seems to have been that social status produced wealth rather than the reverse. The career of men who became "big men" would typically follow three stages. In adolescence and early manhood, before marriage, they would distinguish themselves in fighting - often with no personal concern with the issues that led to the conflict. In the next stage of their careers they would begin to accumulate wives, using in part their prestige from their success in fighting. "People esteem successful warriors" (Glasse, 1968, 87). To be wealthy meant controlling many gardens and pigs, and this in turn required wives to supply the labor. If they are successful in the various conflicts their affinities and marriages inevitably attach them to, they extend their influence and wealth over a wider area through further marriages. One former war leader who became wealth and important had married 21 times by age 50 (Glasse, 1968, 48). 
Similarly Sillitoe reports of Papua New Guinea tribes that though they vary enormously

culturally, they are all "big men" societies where "Big men achieve their positions because they excel in the things that matter in life, they are good talkers, they are courageous, they are skillful in exchanges of wealth.” (Sillitoe, 1978, 253). Success in these societies - status, pigs and wives comes not from skill in production or innovation, but from success in war, social intercourse, and social negotiations.

So the move to societies where violence is centralized and limited seems to be an important social evolution distinct from the achievement of settled agriculture. It was this that changed the nature of competition in societies for reproductive success towards strictly economic means. This evolution took place in some parts of the world, but notably not in others such as the Highlands of Papua New Guinea. This suggests that there was another interesting institutional transition much earlier than the Industrial Revolution, and one that we have little understanding of. Economic history, as George Grantham argues, may indeed have three phases as opposed to two.

\section{Living Standards in 1800 versus the Stone Age}

Both Persson and Voth dispute the notion that material living standards in the world in 1800, and indeed in England in 1800, were no better than in the Stone Age. Persson for example, states,

“He [Clark] dismisses Angus Maddison's painstaking efforts (e.g. Maddison 2001, Maddison, 2003) at providing an empirical basis for long-run income estimates (p. 19) as inconsistent with the logic of the Malthusian economy. When the historical record contradicts Greg Clark it is not allowed to stand in the way..."

I dismissed Maddison's estimates not because they are inconvenient to Malthusian theory, but because they are based on nothing more than Maddison's incorrect assumptions about how 
economies worked before 1800. They are not based on any serious historical evidence. When the facts are inconvenient to Maddison's picture of the world, then the facts are ignored.

Maddison gives estimates of real output per person in the world, and in each region between $1 \mathrm{AD}$ and 1820 that suggest substantial improvements in the Malthusian era. Table 1 summarizes those estimates. At the world level income per person begins to rise sometime after $1000 \mathrm{AD}$, and is 50 percent higher in 1820 than in $1000 \mathrm{AD}$. British income in 1820 is 5 times the Western European average of $1000 \mathrm{AD}$, and western Europe as a whole is nearly twice as rich as in 1000 AD.

Table 1: Income per person, from Maddison, 1 AD to 1820 (\$ 1990 international)

\begin{tabular}{|c|c|c|c|c|c|c|}
\hline Period & World & W. Europe & Asia & Africa & Britain & Japan \\
\hline $1 \mathrm{AD}$ & 444 & 450 & 449 & 425 & 450 & 400 \\
\hline 1000 & 435 & 400 & 402 & 416 & 400 & 425 \\
\hline 1500 & 564 & 773 & 568 & 400 & 762 & 500 \\
\hline 1820 & 667 & 1,232 & 579 & 418 & 2,121 & 668 \\
\hline & & & & & & \\
\hline
\end{tabular}

Source: Maddison (2001), Appendix tables B18, B20, B 21.

Note: For $1 \mathrm{AD}$ and $1000 \mathrm{AD}$ there are no estimates for separate European countries, so the data reported for the UK is for Western Europe as a whole. (I call the earlier date $1 \mathrm{AD}$ as opposed to 0 $\mathrm{AD}$ as in Maddison because technically there was no 0 AD). 
The source of these estimates for the years before 1820, laid out in Appendix B of Maddison (2001), are largely from just one crucial assumption Maddison makes. He assumes a subsistence level of income of $\$ 400$ (Maddison, 2001, 260) that will be found in any society without a sophisticated production technology, without significant urbanization, and without a substantial rich class. The various parts of the world in the first Millennium are assumed to thus have incomes either of $\$ 400$ (uncivilized) or $\$ 450$ (civilized). Where that magical number of $\$ 400$ comes from that does all the work is unclear. Maddison has no estimates from 1820 for income per person for the types of societies this number is supposed to apply to. Because it is significantly less than the income levels assumed for most regions of the world in 1820, inevitably we have economic growth between $1000 \mathrm{AD}$ and 1820. Had Maddison assumed the number was $\$ 600$, there would be no growth from $1 \mathrm{AD}$ to 1820.

Even the estimates for 1500, 1600 and 1700 seem largely ad hoc. In England, one of the economies with well documented economic data back to 1200, Maddison just assumes that that the growth rate of GDP per person in 1500 to 1700 was each year the same as estimated by Nicks Crafts and Knick Harley for 1700-1801, which of course includes part of the Industrial Revolution (Maddison, 2001, 246). He does this despite the real wage evidence for these years which completely contradicts these estimates. In 1500 both farm workers and building workers had higher real wages than in both 1600,1700 and even 1800. Maddison dismisses the real wage evidence of Phelps-Brown and Hopkins (1981) as limited and unreliable. Yet later studies of real wages in England using different sources, while modifying Phelps-Brown and Hopkins conclusions, have confirmed that real wages in the fifteenth century were above those of 1800 (Allen, 2001, Boulton, 2000, Clark, 2005, Clark, 2007b, Rappaport, 1989).

If Maddison is wildly wrong in his estimates of income growth in England 1500-1820, a country for which we have good economic data, then why should we expect him to somehow be 
able to intuit economic growth rates in societies where the data is much poorer. Citing Maddison as a source to refute any of the claims about the world before 1820 made by $A$ Farewell to $A$ lms is thus the equivalent of citing Bishop James Ussher as refuting the theory of evolution. ${ }^{1}$ Only for a very few places - such as England 1200-1820 - do the data exist to allow any systematic estimates of income per person before 1820. These cases, as A Farewell to Alms shows, show none of the rise in income per person over time that Maddison postulates. Other than this we have isolated evidence of real wages, and of proxy measures such as heights. These again, as the book shows, demonstrate no upwards trend in world incomes $1 \mathrm{AD}$ to 1820.

Where Maddison goes wrong is in his assumption that there was one fixed level of subsistence income in the Malthusian era, so that the lowest incomes observed in 1820 must be the natural state of income in earlier years. But the book shows that the level of subsistence varied substantially across societies. It could be very low, as in Japan in 1700-1867, or very high as in England in 1450 , both societies in a Malthusian equilibrium with birth rates equal to death rates. $A$ Farewell to Alms then shows that even taking one of the richest societies in the world in 1800, England, there is no systematic sign that average incomes had risen beyond the Stone Age.

Persson also does not seem to have taken on board the crucial logic that the Malthusian assumption do not imply one fixed level of subsistence income at some biological minimum. He thus attributes to $A$ Farewell to Alms "The proposition that average income was constant." Instead what $A$ Farewell to Alms argues is that while average incomes varied greatly across societies, they showed no trend between the Stone Age and 1800, and incomes were uncorrelated with the technological sophistication of societies. He also incorrectly assumes that the subsistence income before 1800 was some biologically determined minimum.

\footnotetext{
${ }^{1}$ Bishop Ussher was the $17^{\text {th }}$ century Irish clergyman who dated the creation of the universe, based on the evidence of the Bible, to 22 Oct, 4004 BC.
} 
Thus he cites as another refutation of the book's Malthusian thesis the finding by Branko Milanovic that Byzantium incomes around 1000 AD were around \$680 (in 1990 international dollars), and the claim by Raymond Goldsmith that Roman income per capita around 1 AD was as high as $\$ 1,700$ (Milanovic, 2006, Goldsmith, 1984). Since he assumes a biological subsistence income of $\$ 355$, these numbers are supposed to refute the Malthusian thesis. But $A$ Farewell to Alms repeatedly makes the point that incomes before 1800 were almost always well above strict biological subsistence levels. ${ }^{2}$ It also points out that incomes seem to have had little correlation with the technological or administrative sophistication of the society. Tokugawa Japan was a great deal more technologically sophisticated than Ancient Babylonia 4,000 years earlier, yet it had significantly lower living standards.

Voth argues that inventories of English pauper's possessions at death, and working class budgets from England in the 1790s establish that English living standards then greatly exceeded those of the Stone Age, even for the poor.

The pauper inventories come from the elderly who applied for poor relief in return for leaving their possessions to the parish. Voth seeks to use this to get an insight into the average consumption patterns of the poor. But this constituted a relatively select group of the pauper population. Those who were once rich enough to acquire such middle class possessions, but then in old age became destitute enough to need parish support. Those who never owned any such possessions would leave no will, and would thus not be recorded in these pauper inventories. By the accidents of survival anyone could live long enough that they would outlast their savings and be driven eventually to seek parish relief. In England by 1800 nearly $20 \%$ of male testators were aged

\footnotetext{
${ }^{2}$ Persson also does not seem to appreciate that since the numbers of Milanovic and Goldsmith directly contradict the assumptions of Maddison (2001) on incomes in $1 \mathrm{AD}$ and $1000 \mathrm{AD}$, it undercuts his earlier argument that the book erred in rejecting these valuable estimates.
} 
75 or older when they wrote their will. These inventories will give no indication of what even the median income earner in the society possessed in the way of goods.

Voth similarly quotes the budgets of laborer's families in 1788-92 as showing that these were relatively prosperous people. They spent only $69 \%$ of their incomes on food. The other $31 \%$ was composed of $10 \%$ alcoholic drinks, $10 \%$ rent, $5 \%$ fuel and light, and $6 \%$ clothing. But does this show English laborers were better off than hunter-gatherers? The expenditures on rent, fuel and clothing were necessary in the cold climate of England to maintain warmth in the night and in winter. These are not luxury items but simple necessities.

Clothing, housing and heating expenditures were modest in Tahiti in the 1760s when the Europeans arrived. People lived in open-sided unheated huts. Given the climate heavy clothing, elaborate buildings, and extensive fuel supplies were superfluous. The English sailors who preferred to stay in Tahiti than return to London certainly did not see the lack of these expenditures as a hardship.

The English expenditures on these items proves more the dismal nature of the English climate than the luxury of English living standards. Hunter-gatherers in colder climates show a similar pattern of expenditures on food, clothing and shelter to the English. Thus the recent work of Ann Carlos, Frank Lewis and Alexander MacDonald on Cree in Canada in the eighteenth century suggests they had a more generous expenditure on clothing than the English poor. They would use as they raw material for their annual clothing needs 5 mooseskins and 3 deerskins. The clothing was elaborate and often highly decorated (Carlos et al., 2007). Fuel was abundant in Cree society so they did not spend much on this. Shelters were more primitive than in England, but the necessity of constant movement militated against more elaborate structures.

The Cree diet was rich in meat, estimated at about 3 lbs per man per day, meat being a luxury in the diets of the English poor. The Cree also had access to sugars through tree sap, as well 
as wild rice. The difference in consumption bundles makes any exact comparison of living standards very difficult. But the evidence from expenditure shares cited by Voth does not establish any superiority of English living standards above those of the average hunter gatherer.

\section{Has Malthusianism been refuted?}

Living standards may not have shown any trend before 1800. But were they determined regulated by the Malthusian mechanism? Persson argues that "There is in fact a vast literature (e.g. Bailey and Chambers 1994; Lee 1973, 2003; Weir 1984) which by and large is unable to corroborate the existence of the long run Malthusian equilibrium." Grantham notes "Convergence to the Malthusian steady state occurred on the time scale of centuries, not generations, which suggests a weak Malthusian constraint at best.”

In similar vein Persson objects to the parallel between human and animal societies in the Malthusian framework emphasized in A Farewell to Alms. "One of the major flaws of the Malthusian hypothesis is that it lacks a micro-foundation in human optimizing behavior... No known society of humans in the past reproduced at the biological maximum."

It is correct that econometric tests on pre-industrial England and France on annual fluctuations have found at best extremely weak responses of fertility and mortality to short-run shocks to income caused by harvest failures or successes, or long run shocks caused by population growth or decline. If these studies are correct it means that in the short-run income can deviate substantially in any society from the Malthusian equilibrium. It can still be the case, however, that given a sufficiently long interval income will return to the Malthus equilibrium. And it can still be the case that the predictions of the model such as no long run gains in income, and no association of income with better technology, will still hold true in the long run. As Ronald Lee nicely put it, 
summarizing the literature on the operation of the Malthusian mechanism for pre-industrial agrarian populations in Europe,

Almost all short-run temporal fertility variation is density independent. Thus density

dependence is ... a footnote to other theories, a suggestion that in addition to other interesting and

important variables, there is a weak but persistent tug from density effects. It is essential to realize,

however, that as long as there is any trace at all of density dependence, no matter how weak, this tug,

by its systematic persistence, comes to dominate buman population dynamics over the long run, if not

the short. (Lee, 1987, 452).

\section{Social Darwinism?}

McCloskey asserts that the only innovative argument of the book (but see point 7 below), on the evolution of modern economic attitudes, is just worked-over Francis Galton. "Certainly it's a bold hypothesis, and was bold when first articulated by social Darwinists late in the $19^{\text {th }}$ century." Employing a style of argument I find odd for someone who purports to value intellectual enquiry, he re-labels the argument as being about white Übermenchen versus non-white Untermenschen. ${ }^{3}$ Joseph Goebbels himself would have admired the deft use of guilt by association.

In the book I dissociate myself from the whole Social Darwinist enterprise (Clark, 2007a, 112, 186-189). I can only repeat what McCloskey seemingly missed.

Thus is is plausible that through the long agrarian passage leading up to the Industrial Revolution man was becoming biologically better adapted to the modern economic world. This is not in any sense to say that people in settled agrarian economies on the eve of the Industrial Revolution had become "smarter" than their counterparts in bunter-

\footnotetext{
${ }^{3} \mathrm{I}$ am not opposed to the use of rhetoric to help illustrate a point, but the device here is so clichéd, that I would have thought that someone who valued their reputation as a writer such as McCloskey would have resisted such an obvious ploy. There is a folk theorem called Godwin's Law relating to internet chat that states: "As a Usenet discussion grows longer, the probability of a comparison involving Nazis or Hitler approaches one." Apparently so for academic debates also.
} 
gatherer societies.... The argument is instead that is rewarded with economic and hence reproductive success a certain repertoire of skills and dispositions that were very different from those of the pre-agrarian world, such as the ability to perform simple repetitive tasks hour after hour, day after day. There is nothing natural or harmonic, for example, in having a disposition to work even when all basic needs of survival have been achieved. (Clark, 2007a, 187-188).

This is more a story about Überschleppers versus Unterschleppers, than Übermenchen versus Untermenschen. McCloskey is wrong when he claims that I am, like him, an unqualified admirer of bourgeois values. Being a cheerleader for the bourgeois values, as he is, creates a murky entanglement of economics and value judgements that I, at least, want to avoid.

\section{There is no evidence that "survival of the richest" changed pre- industrial genes or culture}

McCloskey asserts that the processes of "survival of the richest" could not significantly effect on the culture or genetics of societies like England by 1800 . He quotes in support the arguments of Sam Bowles in his review of the book in Science (Bowles, 2007).

Adapting one of Bowles' points McCloskey tries to land a knockout blow. Regression to the mean would in a few generations destroy any effects of "survival of the richest" on behavior, by taking descendants back to the average characteristics of the population. Such selection could thus only influence behavior for any descendants of the economically successful for a few generations.

This is just a misunderstanding of the concept of regression to the mean. If McCloskey was right farmyard animals would all be at their medieval sizes still, and instead of the wonderful modern extravagance of dog breeds all dogs would have the characteristics of wolves and would make bad house pets. As a further reduction as absurdum man would never have evolved from apes in the 
first place. Why haven't creationists latched onto this wonderful insight, which according to McCloskey Galton, the great Social Darwinist fully appreciated (and yet clung to Social Darwinism)?

The reason is that if we take a population that varies on some characteristic, such as height, and eliminate the bottom 10 percent of the height distribution in one generation then we will for all time change the average height of that population. This is because we have changed the average underlying average genotype of the population. Because of regression to the mean the long run effect will not be as great as on the current generation. Because of random and environmental effects some of the people we removed had a large genotype, and some people we left in had the small genotype. But all regression to the mean in future generations will be to this higher mean. If we keep removing the bottom 10 percent of the population then over generations average height will keep increasing, and the variance of height diminishing, until we get to the maximum genetic potential for height in the population. ${ }^{4}$

Bowles' point runs into the same reduction ad absurdum. If it was true you could never by any temporary intervention permanently change the characteristics of a population.

McCloskey challenges me to be a true scientist and calculate the quantitative magnitude of the selection process posited. This is a straightforward calculation, and it shows that it would have strong effects. There is ample evidence that even in a few thousand years there could be significant changes in expressed human nature, by processes of inheritance within families. We know from quantitative genetics that this possibility depends just on two parameters:

(1) How hereditable was orientation towards economic success? How much did the economic performance of fathers predict that of sons?

(2) How much reproductive advantage did the rich have?

\footnotetext{
${ }^{4}$ That is, until the genes promoting height become fixed in the population.
} 
Since economic orientation was and is highly hereditable, and it conferred large reproductive advantages, expressed human behavior could change quite quickly in the pre-industrial world.

Note that people's economic behaviors are influenced by three systematic forces: their genes, culture vertically inherited from their parents, and culture horizontally acquired from the society they live in. For purposes of social policy the most important distinction is not between genes and culture, but is between traits acquired within families (which are very hard to change by any social policy) and traits acquired from peer imitation. This is the effect I estimate below. I also show, however, that based on modern evidence the majority of these effects would be genetic.

\section{The Hereditability of Wealth}

Hereditability is simply the correlation between parental behavior and child behavior. It varies greatly across human traits from near 0 to near 1 . To measure this we would need measures of the average characteristics of both parents (since each child has two parents) compared to those of children. Since by law assets in pre-industrial England were controlled by males, we have no direct measure of the economic status of women. With perfect assortive mating the characteristics of both parents would be the same, and we can just look at father-son correlations in wealth. If mating was random, and children inherited characteristics from both parents, then the hereditability would be twice the father-son correlation. It turns out to be a law in genetics that the presence or absence of assortive mating has no effect on how rapidly a trait with a reproductive advantage will spread in a population. So we will not worry too much about this.

Assuming a constant dispersion of incomes the father-son correlation of wealth can be estimated by estimating the coefficient $b$ in the expression

$$
\ln y=b \ln y_{p}+u
$$


where lny is the log of income or wealth of sons (measured relative to the average income), and $\ln y_{p}$ is the log of income or wealth of fathers, measured similarly.

If $b$ is 0 , the trait is completely non-heritable. If $b$ is 1 then the trait is completely passed on from fathers to sons. Since sons only inherit half their genes from their fathers, for a genetically inherited trait we would expect that b should be 0.5 or less (unless mating is assortive when it can be as high as 1). $u$ is the random element in the transmission of traits from parents to children, created by differences in environment and by chance.

For traits important to breeders of farm livestock - milk yield, fleece weight, litter size, body weight - hereditability varies, but averages around $0.4 .^{5}$ This relatively low number implies that most of the variation in features like offspring body weight comes from random features. Yet despite this just by selection on observed characteristics animal breeders have been able over a few hundred years to greatly change the attributes of domestic animals. The medieval cows and sheep in England were tiny compared to their modern equivalents.

Economic success, measured by the correlation of wealth at death between fathers and sons, was much more heritable in the pre-industrial world than the average animal trait. The correlation here, measured as b, for 240 father-son pairs in England 1550-1850 was 0.67.

\section{Hereditability and Human Behavior}

At a lunch in 1936 with the critic Mary Colum, Ernest Hemingway said, "I am getting to know the rich." Colum replied, "The only difference between the rich and other people is that the rich have more money." ${ }^{6}$ If this was true for the pre-industrial world then the differential survival of the rich would have had no long lasting impact on culture or genetics in these societies. The rich got

\footnotetext{
${ }^{5}$ Hartl, 1985, 404.

${ }^{6}$ Eddy Dow, New York Times, Nov 13, 1988. This is the basis for the oft quoted but fictive exchange between Fitzgerald and Hemingway.
} 
established as class by some original act of violent expropriation in earlier times. Then their children inherited this wealth, and the reproductive success that came with it. But this process had no effect on human nature, since the rich were no different from anyone else in the society.

We can show, however, that the rich in pre-industrial England had to be different in personality and culture from the poor. The way we can show this is by estimating the connection between the wealth of sons and fathers controlling for the numbers of children $(\mathrm{N})$. Thus I estimate the coefficients $b$ and $\theta$ in

$$
\ln y=b \ln y_{p}+\theta \ln \left(y_{p} / N\right)
$$

$\mathrm{y}_{\mathrm{p}}$ is the wealth of the father, $\mathrm{y}_{\mathrm{p}} / \mathrm{N}$ the expected bequest received by the son. If the only advantage of rich sons was the bequest received then $b$ should be 0 . If the bequest did not matter then $\theta$ should be 0 .

The estimated coefficients are

$$
\ln y=0.51 \ln y_{p}+0.18 \ln \left(y_{p} / N\right)
$$

While the coefficient on $\ln y_{p}$ is statistically different from 0 , the coefficient on $\ln \left(y_{p} / N\right)$ is indistinguishable from 0 statistically (the standard error is 0.17 ). Though the numbers of children in the fathers' families varied from 1 to 11 , the estimated effect of this on the wealth of the son at death is modest. The best estimate is that the wealth of the son at death depends only $18 \%$ on wealth transmitted from the father. Most of the correlation in the wealth of sons and fathers at death depends on the transmitted of talent from fathers to sons, either genetically or culturally.

Thus we know that in pre-industrial England economic success was highly hereditable, and that this was mainly because the children of the rich differed genetically or culturally from the general population. Note also, since this will matter below, that there is a very modest quality/quantity tradeoff with sons in pre-industrial England. Moving from a family of 2 children to 
one of 4 children would reduce the expected wealth of sons by $12 \%$. Moving from 2 to 10 children reduces sons expected wealth by just $25 \%$.

\section{Changing Human Nature}

Suppose for simplicity we assume that economic success mainly came from possession of some complex trait, $Z$, which depended on the inheritance of a favorable draw of many factors. We can be agnostic for the moment about whether this was passed on genetically or culturally. This trait, for example, would include how many hours of work effort people put in each day, and how patient people were. Suppose also $y=Z+e$, where e is the random component. Income or wealth depends on how much of the trait you possess. How fast could such a trait spread among the population in the reproductive conditions of pre-industrial England, given that the possessors of the trait had twice the number of surviving children than those who did not possess it, but there was imperfect transmission between parents and children?

Figure 1 shows an assumed initial distribution of income y, assumed to follow a normal distribution with mean of 0.5 . Figure 1 also shows the distribution of income among the offspring, with the assumption of a hereditability of 0.6 from father to son. That is

$$
\ln y=0.6 \ln y_{p}+u
$$

For simplicity I assumed that the top quartile of the population had 3.2 surviving children, the next quartile 2.4, the next 1.6 and the lowest 0.8 .

With these assumptions the average level of $y$, and hence of the trait $Z$, in the next generation increases by nearly $7 \%$ on the base. Thus even one generation in pre-industrial England is enough to change the distribution of the expressed trait significantly. Assuming an average generation length of 33 years there would be 18 generations between 1200 and 1800, plenty of time

for significant changes in peoples' economic aptitudes. If we take the much longer interval between 
the Neolithic Revolution and the Industrial Revolution we are talking about 8,000 years, 240 generations. That is time enough for quite significant changes in the way people behaved.

Figure 1: The Change in Distribution of Economic Abilities over One Generation in Preindustrial England

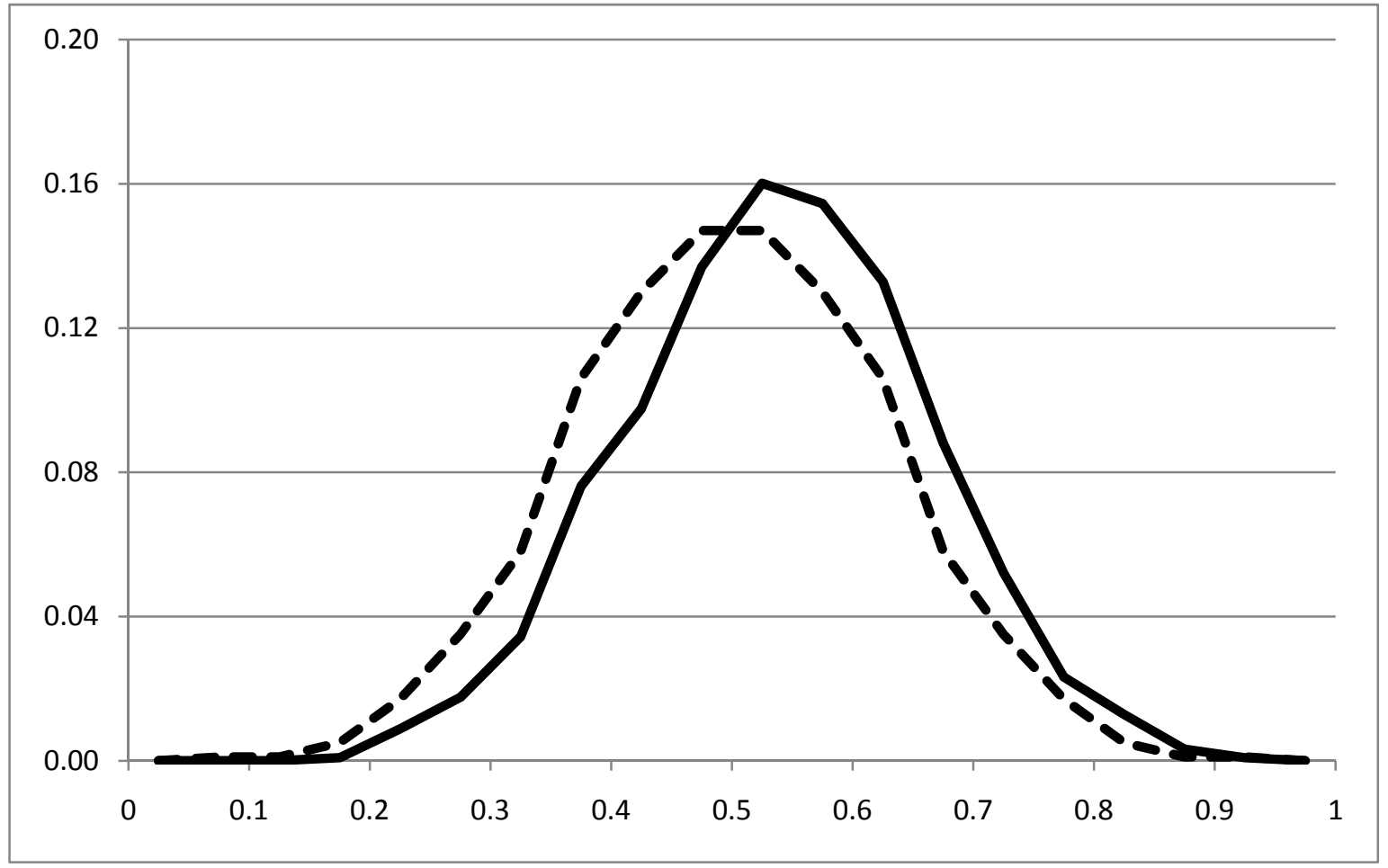

Another interesting feature of this change is that the variance of economic abilities declines as a result of this selection process. From one generation to the next people become more alike in their underlying economic abilities $Z$, and that the distribution of y becomes more peaked over time. The evolutionary process would not just raise the mean, it would also reducing the dispersion. 


\section{Could this change be genetic?}

We see changes in basic behaviors before 1800. We see also the much greater reproductive success of those who embodied the more modern economic behavior. Economic success was strongly inherited, but that the mechanism of inheritance was not mainly the inheritance of wealth.

The mechanism of inheritance might still be purely cultural, a culture passed down vertically within families. For practical purposes of social policy this has the same impact as genetic inheritance, since the overwhelming majority of children are raised by their genetic parents. If this is a process that differed in its impact between one society and another, it does not matter whether the transmission mechanism between generations was genes as opposed to culture within families. It will be equally difficult to change through social policies that operate only outside families.

If one society experienced this process for a longer time, or more severely, than another then its members would have a persistent advantage in economic competition whatever the source of this advantage. But it is still intriguing to ask whether the processes I have identified could affect significant genetic changes in the historical era.

To conclude that the mechanism was genetic changes we need further information. But there is such information that makes this a very real possibility.

The rich in modern industrial society are genetically different from the poor. Stated thus boldly and starkly this seems a shocking, elitist statement. But this genetic difference shows in a number of ways.

First we can look at how closely the incomes of identical twins resemble each other compared to same-sex fraternal twins. Most of these studies have been done on males. With random mating by parents identical twins share $100 \%$ of their genes and fraternal twins only $50 \%$. Under any reasonable assumption the environment will be very similar for fraternal as for identical 
twins. $^{7}$ If genetics made no difference to income, which was determined only by a combination of environment and chance, the correlation of income for identical and fraternal twins would be the same. In fact studies of twins consistently show the correlation of income for identical twins is about 0.2 greater than for fraternal twins (where the correlation can range from 0 to 1 ). ${ }^{8}$ If the two parents have no genetic commonalities this would imply that genetics explains about .2 of the observed correlation of 0.4 between the incomes of brothers.

But marriage is to some degree assortive. People marry those who are like themselves in education and income. If there is an important genetic element in the determination of education and income, that in turn implies that people tend to marry those genetically similar. This means that even fraternal twins share more than $50 \%$ of their genetic material. The higher correlation of incomes between identical as opposed to fraternal twins is thus based on even less difference in genetic material, and so genes must be even more powerful in shaping income. With reasonable assumptions about the degree of assortiveness in modern mating, genetics can then explain .25 of the correlation of .4 between brothers' incomes.

The second source of information we have is the outcomes for biological children compared to adopted children. A recent study for Sweden, using an extraordinary good data set that identifies for children the education levels of both their adoptive and biological parents, finds that both nature and nurture matter to the educational attainment of children. But interestingly the relative impact of

\footnotetext{
${ }^{7}$ Some have argued that identical twins will have a more equal environment than fraternal twins, and this will account for the higher correlation in their outcomes. But if outcomes were so responsive to such modest changes in family environments then we would expect that social policies designed to address poor outcomes for some social groups which create similarly modest differences in the environment of children would be much more efficacious than they have proved to be.

${ }^{8}$ Bowles and Gintis (2002), 14.
} 
the biological parents is roughly double that of the adoptive parents. ${ }^{9}$ This is not directly evidence on income and wealth, but education levels are important predictors of both of these. And clearly genes explain the majority of educational attainment in modern Sweden.

Studies of criminality, using either twins or adoption methods, have similarly revealed a similarly strong genetic connection. One classic study is that of 14,427 Danish adoptees where the court convictions of the adoptees, their biological parents, and their adoptive parents are all known. When both sets of parents were non-criminal, the chances of the adoptee being convicted for a crime were $13.5 \%$. When only the adoptive parent had a criminal record this chance rose very slightly to $14.7 \%$. However if only the biological parent had a criminal record the chance of the adoptee having a criminal record rose much more, to $20.0 \%$. If both sets of parents had a criminal record the chance of the adoptee having such a record was $24.5 \%$. This suggests that genetic influences on the propensity to crime are much greater than environmental influences. ${ }^{10}$

Could the same forces identified above also cause significant genetic change over the course of 20-200 generations?

To simplify let there now be some genetic factor, a continuous variable $g$ since it is the result of alleles at many loci, which helps determine economic success - the capitalist gene. Evidence from the twin studies cited above suggests that

$$
y=0.5 g+u
$$

Thus a person who has economic success two standard deviations above the average will typically have a "capitalist potential" just one standard deviation above average. The rest of their success will be a combination of luck, bequests, and the environment they grew up in.

\footnotetext{
${ }^{9}$ Bjorklund, Jantti, and Solon, 2007.

${ }^{10}$ Mednick, et al., 1984.
} 
Since we have assumed these genes have additive effects, if we take the average of parents economic success, we will find that their children have the same score on the "capitalist gene" index as the average of their parents (since all their genetic material comes from their parents). If marriage was purely random, and economic success depended only on the performance of men, then the son of a man two standard deviations above the mean in terms of economic success would be only 0.5 standard deviations above average in terms of his genetic potential for economic success. That would still imply that there was significant shift in the genetic composition of the population in each generation: a $2.5 \%$ increase on this measure per generation.

But marriage was not random in the pre-industrial world, at least in England and probably in most societies. Brides received dowries from their parents, and they in turn expected their children to inherit from their father-in-laws. So there was close matching in the economic status of partners in most marriages. If we assume on average that men married women whose father's had equal economic status to theirs, then by iteration the average bride would have as much of the capitalist gene as her husband. In this case, based on figure 1 above, there would be a $5 \%$ gain in the presence of this characteristic in the genetic makeup of the pre-industrial English per generation. Further two thirds of the changes in economic behaviors would indeed have genetic origins.

Sam Bowles objects that while personality traits are associated with economic success in the modern world, the hereditability of personality traits tends to be very low (Bowles (2007)). The hereditability of such traits was estimated in a large meta-study to average $0.13 .{ }^{11}$ Thus there would be very weak selection for such traits in the pre-industrial world. However, evidence that specific traits measured by psychometricians have low hereditability does not on its own imply that a collection of traits that ensure economic success also has low hereditability.

\footnotetext{
${ }^{11}$ Loehlin, 2005.
} 
For example, one of the most hereditable features of humans is the total ridge count across their 10 fingers, where the correlation between the average parent count and child count is 0.96. Yet for any given finger the hereditability of the count is only $0.63 .{ }^{12}$ The reason is that at the level of single digits environmental and accidental features are much more important than when we average across 10 digits.

Similarly when psychometricians attempt to measure the hereditability of any particular feature of personality chance and environment may suggest a low value. The IQ of adults is highly hereditable ( 0.7 or more), and an important predictor of economic success. But these IQ scores are the composite of performance on a number of subtests (11 in the Wechsler intelligence test), where the hereditability of these subtest scores is much lower.

The precise way in which genetics influences economic success is not known. Factors such as IQ matter, but on their own explain very modest amounts of economic success. Other personality measures can also be shown to play some role. But since psychometricians have not set our systematically to find the personal predictors of economic success we do not know much about this. But we do not need to know exactly what these personality correlates are to know that they could have been strongly selected for within a few thousand years in the pre-industrial world.

The degree to which genes as opposed to chance or environment dictate outcomes is also dependent on the amount of variation in both genes and environment. It is not an absolute, but depends completely on such things as the range in social environments across families. In a society where $90 \%$ of people are bound serfs, and 10\% own all the capital, environment will be a much more important predictor of outcomes than genetics. In a society like modern Sweden with extensive educational and health provision by the state, genetics may explain much more of economic success than otherwise.

\footnotetext{
${ }^{12}$ Falconer, 1981, 160-1.
} 
However, from at least the middle ages, pre-industrial England was a society with a very

open structure. Most occupations were open to all, and anyone could accumulate property such as houses or land. There was every possibility for genetics to have an influence on outcomes even from the earliest years.

\section{Conclusion}

About 8,000-10,000 years ago people discovered the benefits of sedentary agriculture and began abandoned their roaming hunter-gatherer lifestyle. In the process they domesticated a large number of plants and animals. The wolf became the dog, the wild boar the farmyard pig.

Dogs, cattle, sheep, pigs, chickens all were transformed from wild animals to domesticated servants of humanity. In the process fundamental aspects of their natures were changed. Dogs have their origin in East Asian wolves of about 15,000 years ago, but they have acquired traits wolves do not possess. Thus dogs can read human faces and human actions in a way that wolves cannot, even when wolves are socialized with people from birth as with dogs.

Until recently, however, the one creature in the modern farmyard that was believed to be unchanged from Paleolithic times was man himself. We were assumed to still our original wild form. Thus there has been much attention to the "stone age mind" of modern man, and how this fits poorly with our new habitat of cities, crowds, and nations (Cosmides and Tooby, 1997).

But the evidence from pre-industrial England suggests that economic success was highly hereditable. Given how hard it is to change by social policy traits that are acquired within families, this, in terms of modern social impact it does not matter whether the mechanism of inheritance was genetic or not.

But evidence from the modern world establishes that economic success has a very important genetic component. Putting these together we can establish that there must have been significant 
genetic change from generation to generation in this dimension in societies like pre-industrial England.

This evidence fits well with recent claims that the rate of evolution among humans speeded up in the past 10,000 years. A recent study of variations in DNA across individuals concluded that "Rapid population growth has been coupled with vast changes in cultures and ecology, creating new opportunities for adaptation. The past 10,000 years have seen rapid skeletal and dental evolution in human populations, as well as the appearance of many new genetic responses to diet and disease."13 In one particular case, the evolution of lactose tolerance has been traced in Northern Europeans to only the last 5,000-10,000 years. ${ }^{14}$

\section{Does modern experience refute the idea of a genetic substrate to}

\section{capitalist success?}

McCloskey citing the review of the book by Robert Solow, argues that the experience of countries like India and China recently, and of immigrants to the US, shows that the idea that there are deep seated cultural or genetic differences in peoples' ability to succeed economically, which stem from the long histories of these societies, is unsupportable.

On the contrary, I think that there is a lot of modern evidence that is supportive of this possibility. What is emphasized in A Farewell to Alms is that the processes identified for England occurred in all settled pre-industrial agrarian societies, though perhaps with different force. That suggests that if we want to find the maximum possible cultural and genetic difference between groups in the modern world we should contrast the people from long settled agrarian societies with

\footnotetext{
${ }^{13}$ Hawks et al., 2007, 20,753.

${ }^{14}$ Bersaglieri, 2004.
} 
those from hunter-gatherer societies that never experienced settled institutionally stable agricultural systems. Can McCloskey point to a single hunter-gatherer group that has successfully and quickly adapted to modern capitalist economies? Australian Aboriginals? The Hmong here in the USA?

Also can he explain why when Chinese and Indian indentured laborers were exported to various parts of South America, Africa, South East Asia and the Pacific in the colonial period they

have tended to do very well economically? Unlike white settlers, these were unskilled laborers with no capital and no political advantage as the overlords of these societies. Yet in societies like Fiji, Mauritius, Kenya, Uganda, the Philippines, Peru, and Suriname they have succeeded economically much better than the indigenous population.

Why are there persistent income gaps between the indigenous population in most countries of the Americas and immigrants from Europe or Asia? Why is income per capita in the America's in part predictable from the share of the population which is indigenous? Why do indigenous groups emigrating to the US from Mexico and Gautemala tend to do poorly economically?

Clearly the long histories of societies are not the only thing influencing current income levels and growth rates. But I think there is absolutely no cause to be confident that these things do not matter.

\section{Intellectual Piracy?}

Though A Farewell to Alms cites 400 articles and books in the bibliography, three of the four reviewers suggest that the bulk of the book is mere unacknowledged borrowings from others. Persson, for example, notes on the Malthusian hypothesis "this book is the widescreen version of the Postan Thesis, although M. M. Postan $(1966,1972)$ is remarkably missing in the credits.” As 
noted McCloskey notes of one of the main arguments of the book, on the evolution of modern economic attitudes, is just worked-over Francis Galton

This sort of reasoning was all fresh and new in 1901, and was still influential after the Great War, resulting in places like Norway, Sweden, and the United States in compulsory sterilization programs, brought to an end only in the 1970s. It even survived its application in Germany. It still attracts the quantitative and mechanical mind.

Further he notes "Much of the book is uncontroversially good, a very good review for outsiders of what economic historians have learned since, say, Karl Polanyi." McCloskey in particular accuses me of unjustly failing to credit two of his papers - one on productivity growth in the Industrial Revolution, the other on the movement of interest rates in England between 1300 and 1800 as revealed by grain prices (McCloskey (1981), McCloskey and Nash (1984)). But he concludes generously that

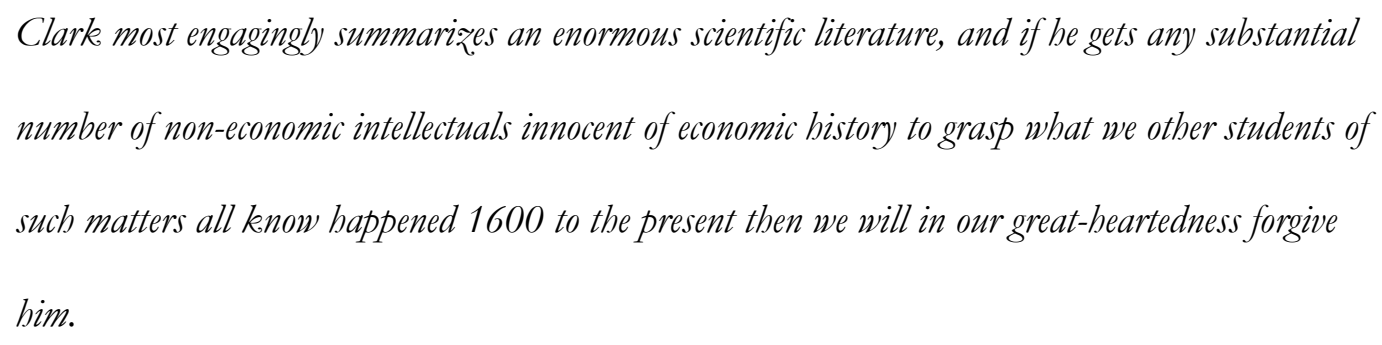

Voth in turn asserts that the major lines of argument in the book are merely trivial extensions of the theoretical work of Oded Galor and Omer Moav (Galor and Moav, 2002): “Clark mainly adds some fragmentary and unrepresentative evidence."

It is certainly something of a surprise to go overnight from an honest academic yeoman, whose 36 papers published over 23 years have never raised such issues, to being accused of being a modern day Captain Kidd of intellectual piracy. I think the form and style of the book is the main explanation for this mistaken allegation, rather than my having decided in middle age to hoist the Jolly Roger in place of the Union Jack. 
The book ranges over a vast terrain in terms of institutions, economic data, and ideas. It was consciously targeted at a wider audience than the perhaps 200 professional economic historians that constitute the staple audience for articles in economic history: economists, others in social science and history, and indeed any intelligent reader. The text thus had to be taut, sparingly footnoted, and leave room for illustrations. It also had to explain economic concepts known to professional economic historians such as the marginal product of labor, and the rate of return on capital. It was a constant struggle to keep the length of the book from exploding. At 420 pages it is significantly longer than planned. The bibliography alone occupies 25 pages. Another constraint was that the conventions of the Press demanded that any item in the bibliography had to be referenced by a footnote, table note, or figure note in the text. The text thus already contains references to about 400 items.

What this implied was that when I cited certain facts, such as the decline of interest rates between Ancient Babylonia and 1800, I did not elaborately articulate the history of how this fact came to the attention of economic historians, or the history of how I, personally, had learned this fact. They are just cited as facts, with the appropriate evidence. They are NOT cited as facts I discovered. McCloskey, when he accuses me of citing in the book "his own way of measuring the European fall of interest rates $1300-1600 \ldots$ without mentioning that I had discovered the fall and measured it in another statistical way ten years before he did (McCloskey and Nash, 1984)" is thus reading into the text something that simply is not there. Read pagers 167-172 and you will see that make no claim to have discovered the long secular decline in interest rates.

I did not cite McCloskey and Nash (1984) in the book for three reasons. Though it is a fascinating and ingenious article, the method it uses to measure interest rates from the rise in grain prices between harvests is much noisier than the method used in the book (McCloskey and Nash consequently estimate medieval interest rates at 30-80\% or more, which is far too high). Once you 
have the data for the preferred method used in the book (land rents versus prices), the grain price information adds little. Second, to make the citation intelligible, to make it add anything to the story, I would have to take a paragraph or more to explain the connection between within -year grain price movements and interest rates. I considered doing that, because it is an interesting economic application, but in the end decided that it did not justify the space required.

Finally, clever and original as the 1984 McCloskey and Nash article is, and important as it was in stimulating my personal interest in this subject, they were not the first to notice high medieval interest rates. Indeed the phenomenon was widely known among earlier economic historians. Alfred Marshall's Principles of Economics, for example, discusses this (see Clark, 1988, footnote 1, 265). Both M. M. Postan and H. J. Habakkuk were aware of high medieval interest rates (e. g. Habakkuk (1952), 44). But if we are less parochial, this is after all the European Review of Economic History, we can date the knowledge of high medieval interest rates at least as early as Max Neumann's book of 1865 on the history of German interest rates (Neumann, 1865).

To thicken the plot, in Clark (1988) I stated the history of medieval interest rates thus in the first paragraph

But though it has been known since the mid-19th century that medieval interest rates were high, the timing, the extent and the consequences of this decline have not been fully explored before... Building on an interesting paper by Habakkuk. (1952) which was mainly concerned with the $16^{\text {th }}$ and $17^{\text {th }}$ centuries I show that interest rates in England fell.... (Clark, 1988, 265).

The article goes on to survey the sources and discussions on medieval interest rates, most of them predating McCloskey and Nash (1984). Deidre McCloskey saw a draft of this 1988 article before publication, and did not register any objection to this history either before or after publication. His claim now that "..I had discovered the fall and measured it in another statistical way ten years before he did..” thus contains two errors. I never claimed this as a discovery, and 
McCloskey is claiming to have discovered something known to English economic historians at least 100 years earlier.

On McCloskey's first complaint, the use of the growth decomposition method without citing his 1981 article, I am more sympathetic. Again I make no claims to originality in the book, as readers can confirm (pp. 233-4). And the decomposition concludes with a very different result than was the key conclusion of McCloskey (1981). I was treating the technique as something so well established within economic history that, just as with calculus we no longer cite Newton (or should it be Leibniz?) every time we take a derivative, so with this technique. But on reflection McCloskey's article is so clever and influential, that even though it is now dated, the policy I adopted not to include references that concern only the history of economic history as a discipline does not do justice, and I should have included a note pointing out McCloskey's role in popularizing this technique in economic history.

As to Persson's complaint about the absence of Postan, though he was an enormous figure in the development of English medieval economic history, and though he gave great importance to population movements in explaining English developments, he had no clear conception of the Malthusian model in his analysis, and none of his work is actually used in the book. So it made little sense to cite him.

As to McCloskey's conclusion that the only part of the book which is not entirely a staple of modern economic history is the part about evolution, I can only refer him to his three co-critics, each of whom objects vigorously to the material he labels as jejune and accepted. The empirical evidence here is that the book contains much that is controversial.

In the end, it is hard to find the correct line in terms of how detailed to make the references between the twin imperatives of readability and of explicit recognition of the efforts of others. I probably did not always draw that line at the right place, giving too much weight to readability. Had 
I produced the same book as a 1,000 page tome with careful attention to the history of knowledge in each area, rather than just a simpler statement of the state of knowledge, then I am sure it would have been more warmly received by the other 200 economic historians. And they would have constituted the entire readership of the book.

Voth's conclusion that the evolutionary argument in the book is just a footnote to Galor and Moav (2002) is perhaps understandable given that Voth believes Galor and his co-authors have solved all the problems of long run growth.

Unified growth theory in the tradition of Galor and Weil (2000, American Economic Review, 89, 806-828) and Galor and Moav (2002, Quarterly Journal of Economics, 177(4), 1133-1191) captures the key features of the transition from stagnation to growth over time. (Voigtländer and Voth (2006), ---).

However Voth must have limited understanding of these papers. For elsewhere in the same article Voigtländer and Voth state:

Unified growth theory (Galor and Weil, 2000; Galor and Moav, 2002; Hansen and Prescott, 2002; Jones, 2001) offers a consistent explanation of the transition from century-long Malthusian stagnation to rapid growth.

The arguments in Galor and Weil (2000) and Galor and Moav (2002) are in fact completely at variance with those of Hansen and Prescott (2002) and Jones (2001). Since Voth cannot detect any distinction in these radically different approaches, it is not surprising that he cannot understand that other than in using natural selection as a mechanism, the data and conclusions in $A$ Farewell to Alms are inconsistent with Galor and Moav (2002). ${ }^{15}$ Galor and Moav (2002) which is an ingenious and elaborate theoretical approach, crucially operates through parents having different quality/quantity

${ }^{15}$ Based on this evidence, if you went to the zoo with Voth, he would be puzzled at why cage after cage throughout the zoo had just duplicates of the same creature. 
preferences for children. The Industrial Revolution is sparked when enough high quality types emerge, to drive up the rate of technological advance, drive up the premium for quality, and so reduce fertility in favor of even more quality. The empirical events of the actual Industrial Revolution do not support this theoretical approach.

(1) Before the Industrial Revolution we can detect no level of income at which net fertility declines, which would be an implication of this model.

(2) Before the Industrial Revolution we see no sign of the quality/quantity tradeoff which drives the model. Controlling for the fathers wealth, sons of fathers with 1 child do about as well economically as those with fathers with 11 children.

(3) In the first 100 years of the Industrial Revolution there is no change in fertility behavior among the rich and educated. Declining net fertility by this group appears only after the Industrial Revolution is well established.

(4) There is no sign of an increased skill premium along with or after the Industrial Revolution. Indeed instead as the book illustrates the skill premium actually declined in the years leading up to the Industrial Revolution, and continued to decline thereafter.

While the book, however, uses the device that Galor and Moav employ elegantly in their theoretical model of Malthusian pressures changing population characteristics in agrarian societies, as McCloskey has eagerly pointed out this idea has a long history, going all the way back to Darwin himself. That is why the chapter on "survival of the richest" is titled "Malthus and Darwin." I do not claim any originality to the idea that Darwinian selection was changing people in agrarian societies, but neither can Galor and Moav. What is original to them, and ingenious, is the idea of selection along the child quality/quantity dimension.

On the empirical work of the book in these two chapters Voth, as noted, sniffs that "Clark mainly adds some fragmentary and unrepresentative evidence." With more than 4,000 wills coded, 
800 of the testators linked to the parish records, and 250 pairs of fathers and sons linked, I would opine that this part alone of the "fragmentary and unrepresentative evidence" took more time to compile than the entire set of data that formed the basis for Voth's own book on work hours in eighteenth century London (Voth (2001)). When economic history has friends like these, who give solid empirical work the weight of a flea to an elephant in comparison with theoretical speculations, it is no wonder that the subject is under threat.

\section{Bibliography}

Allen, R. C. (2001). “The Great Divergence in European Wages and Prices from the Middle Ages to the First World War.” Explorations in Economic History, 38(4): 411-448.

Bar-Yosef, O. (2002). “The Upper Paleolithic Revolution.” Annual Review of Anthropology, 31: 363393.

Bersaglieri, T., P. C. Sabeti, N. Patterson, T. Vanderploeg, S. F. Schaffner, J. A. Drake, M. Rhodes, D. E. Reich and J. N. Hirschhorn (2004). "Genetic Signatures of Strong Recent Positive Selection at the Lactase Gene” American Journal of Human Genetics 74(6): 1,111-1,120.

Boulton, J. (2000). "Food prices and the standard of living in London in the 'century of revolution', 1580-1700." Economic History Review 53 (August): 455-492.

Bowles, S. (2007). “Genetically Capitalist?” Science, 318, 394-5.

Bowles, S. and H. Gintis (2002). "The Inheritance of Inequality” Journal of Economic Perspectives. Volume 16, Number 3, 1 August 2002, pp. 3-30(28) 
Bjorklund, Anders, M. Jantti, and G. Solon (2003). "Influences of Nature and Nurture on Earnings Variation: A Report on a Study of Various Sibling Types in Sweden," in Samuel Bowles, Herbert Gintis, and Melissa Osborne (eds.), Unequal Chances: Family Background and Economic Success. New York: Russell Sage Foundation.

Bjorklund, A., M. Jantti, and G. Solon (2007). "Nature and Nurture in the Intergenerational Transmission of Socioeconomic Status: Evidence from Swedish Children and Their Biological and Rearing Parents." The B.E. Journal of Economic Analysis \& Policy: Vol. 7 : Iss. 2 (Advances), Article 4. http://www.bepress.com/bejeap/vol7/iss2/art4

Carlos, A., and F. D. Lewis (2008). Indians, the Beaver and the Bay. Book Manuscript.

Carlos, A., F. D. Lewis and A. C. MacDonald. (2007). "Nutrition and the Standard of Living in the Mid-Eighteenth Century: A Comparison of Natives in the Canadian Sub-Artic and Europeans.” Manuscript, Queen’s University.

Clark, G. (2005). “The Condition of the Working-Class in England, 1209-2004” Journal of Political Economy, 113(6): 1307-40.

Clark, G. (2007a). A Farewell to Alms: A Brief Economic History of the World. Princeton: Princeton University Press.

Clark, G. (2007b). “Farm Wages, Population and Economic Growth, England, 1209-1869” Economic History Review, 60(1): 97-135.

Cosmides, L. and J. Tooby (1997). “Evolutionary Psychology: A Primer.” UCSB.

Diamond, J. M. (1997). Guns, germs, and steel: the fates of human societies. New York : Norton.

Falconer, D. S. (1981). Introduction to Quantitative Genetics. 2 nd. Edition. Longman: London.

Galor, O. and O. Moav (2002). "Natural Selection and the Origin of Economic Growth." Quarterly Journal of Economics, 117: 1133-1191. 
Galor, O. and D. N. Weil. (2000). "Population, Technology and Growth: From Malthusian Stagnation to the Demographic Transition and Beyond." American Economic Review 90: 806828.

Glasse, R. M. (1968). Huli of Papua: A Cognate Descent System. Paris: Moulton and Co.

Goldsmith, R.W. (1984) An Estimate of the Size and Structureof the National Product of the Early Roman Empire, Review of Income and Wealth, 30 (3), pp.263-88.

Habakkuk, H. J. (1952). “The Long-Term Rate of Interest and the Price of Land in the Seventeenth Century." Economic History Review, 5(1): 26-45.

Harlt, D. L. (1985). Our Uncertain Heritage: Genetics and Human Diversity. New York: Harper and Row.

Hawks, J., E. T. Wang, G. Cochran, H. C. Harpending, and R. K. Moyzis (2007). "Recent Acceleration of Human Adaptive Evolution.” Proceedings of the National Academy of Sciences, 104(52): 20,753-20,758.

Ishikawa, S. S. and A. Raine (2002). "Behavioral Genetics and Crime," in J. Glicksohn (ed.), The Neurobiology of Criminal Behavior. Norwell: Kluwer Academic Publishers, 81-110.

Lee, R. (1987). "Population dynamics of human and other animals," Demography 24: 443-465. Loehlin, J. C. (2005). "Resemblance in Personality and Attitudes between Parents and Their Children: Genetic and Environmental Contributions.” In S. Bowles, H. Gintis and M. Groves, Unequal Chances: Family Background and Economic Success. Princeton: Princeton University Press, 192-207.

McCloskey, D. N. (1981). “The Industrial Revolution 1780-1860: A Survey,” in R. Flood and D. N. McCloskey (eds.), The Economic History of Britain since 1700, 103-127. Cambridge: Cambridge University Press.

McCloskey, D. N. and J. Nash (1984). "Corn at Interest: The Extent and Cost of Grain Storage in Medieval England." American Economic Review, 74(March): 174-187. 
Maddison, A. (2001). The world economy: A millennial perspective. OECD, Paris.

Maddison, A. (2003). The World Economy: Historical Statistics, Paris :Development Centre Studies, OECD

Mednick, S. A., W. F. Gabrielli Jr, and B. Hutchings (1984) “Genetic influences in criminal convictions: evidence from an adoption cohort” Science 25 May 1984: Vol. 224. no. 4651, $891-894$.

Milanovic, B. (2006). “An Estimate of Average Income and Inequality in Byzantium around Year 1000," Review of Income and Wealth, 52 (3): 449-70.

Neumann, M. (1865). Geschichte des Wuchers in Deutschland bis zur Begründung der heutigen Zinsengesetze (1654). Halle: Verlag der Buchhandlung des Waisenhauses.

Phelps Brown, H. and S. V. Hopkins (1981). A Perspective of W age and Prices. London: Methuen. Rappaport, S. (1989). Worlds Within Worlds: Structures of Life in Sixteenth-Century London. Cambridge: Cambridge University Press.

Solon, G. (1999). "Intergenerational mobility in the labor market," in Handbook of Labor Economics, Vol. 3A, Orley C. Ashenfelter and David Card (eds.), Amsterdam: Elsevier.

Sillitoe, P. (1978). "Big Men and War in New Guinea.” Man, 13 (2): 252-271.

Stiner, M. C. , N. D. Munro, T. A. Surovell, E. Tchernov and O. Bar-Yosef (1999). "Paleolithic Population Growth Pulses Evidenced by Small Animal Exploitation.” Science, New Series, 283 (5399): 190-194

Voigtländer, N. and H.-J. Voth (2006). "Why England? Demographic factors, structural change and physical capital accumulation during the Industrial Revolution." Journal of Economic Growth, 11: 319-361.

Voth, H.-J. (2001). Time and Work in England, 1750-1830. Oxford: Clarendon Press. 